\title{
The Economy, Corruption, and Conditional Voting: A Cross-National Analysis
}

\author{
Jungsub Shin
}

The state of the economy and the extent of corruption have been considered two significant factors predicting the success of incumbent parties in elections. However, the effects of economic growth and the perceived level of government corruption on an incumbent party's electoral fortunes vary across countries. Why do the strengths of economic voting or corruption voting vary and under what conditions does their influence become weaker or stronger? This paper attempts to answer these questions using the following rationale: the economy may become a less salient election issue in affluent societies, or other competing issues such as corruption may become more salient. Similarly, corruption may become less salient in trustworthy societies, or other competing issues such as the economy may become more salient. Based on this logic, this paper hypothesizes that economic voting becomes weaker as a country's national wealth increases (based on GDP per capita) and as voters' perceived level of government corruption increases. Moreover, corruption voting becomes weaker in countries where government is perceived to be highly accountable and when there is great progress or severe downturns in economic growth. By examining 92 elections from 41 democracies between 1996 and 2011, this paper finds empirical evidence supporting the hypotheses. The strength of the relationship between economic growth and an incumbent party's vote share decreases as GDP per capita or perceived level of government corruption increases, whereas the extent to which perceived government corruption influences incumbent party vote share decreases as the absolute level of government corruption increases or GDP per capita severely changes.

Key Words: economic voting, corruption voting, conditional voting, democratic accountability

$\mathrm{W}$ hat conditions promote or hinder incumbent leaders' electoral success in democratic countries? The economy and corruption have been regarded as two of the most important factors to decide an incumbent leader's electoral success. On the one hand, many studies have shown evidence that the

*Jungsub Shin(jsshin.polisci@gmail.com) is a research professor at the Institute for Euro-African Studies at Hanyang University. His research focuses on voting behavior, political campaigns, and elections. In particular, he has been empirically exploring the impacts of various government performance outcomes on voting behavior and elections. 
popularity and electoral fortunes of incumbents were highly influenced by the economy's performance, from the earliest studies focused on the United States (Key 1966; Mueller 1970; Tufte 1978; Fiorina 1981; Kiewiet 1983) to more recent comparative ones (Van der Brug et al. 2007). On the other hand, many studies have found that voters punished candidates accused of corruption (Peters and Welch 1980; Fackler and Lin 1995; Chang and Golden 2004; Slomczynski and Shabad 2011; Klašnja and Tucker 2013), so that an increase in the level of government party corruption caused a loss in its vote share (Krause and Méndez 2009).

However, the magnitude and nature of economic voting across elections have varied from country to country, and even within a country over time (Powell and Whitten 1993; Whitten and Palmer 1999; Nadeau, Niemi, and Yoshinaka 2002, Duch and Stevenson 2006, 2008; Anderson 2007), and so has corruption voting (Krause and Méndez 2009; Klašnja, M. and Tucker, J. A. 2013). In response, recent studies of economic and corruption voting have asked under what conditions voters did not care about the economic performance or corruption level of incumbent governments. In the literature, political institutions mostly have been singled out as the cause of different levels of economic and corruption voting (Anderson 2007; Hellwig 2010; Krause and Méndez 2009). ${ }^{1}$

Based on Singer's (2011b) empirical findings about the issue salience of the economy and corruption across countries, however, this research develops new conditional economic and corruption voting hypotheses and empirically tests them. First, it is predicted that the strength of economic voting is determined by the absolute level of national wealth. Specifically, economic voting becomes weaker as the country's national wealth increases because voters are less likely to care about the economy as their country becomes wealthier. Second, it is predicted that the strength of corruption voting is determined by the absolute level of government corruption. In the same vein, corruption voting becomes weaker as the absolute level of government corruption decreases because when a government's level of corruption is low, voters are less likely to regard corruption

${ }^{1}$ Although several conditional economic voting hypotheses have been examined, there are primarily four electoral-focused hypotheses that recur: high vs. low clarity of responsibility elections (Powell and Whitten 1993; Whitten and Palmer 1999; Nadeau, Niemi, and Yoshinaka 2002; J. Anderson 2000; Nadeau et al. 2002; D. Anderson 2006), presidential vs. parliamentary elections (Hellwig and Samuels 2007; Hellwig 2010), left vs. right incumbent government elections (Powell and Whitten 1993; Whitten and Palmer 1999; Vavreck 2000; Hellwig 2012), and new democracies vs. consolidated democracies (Hellwig 2010). Among these conditional economic voting hypotheses, the clarity of responsibility hypothesis has been consistently replicated and confirmed by many studies (Whitten and Palmer 1999; J. Anderson 2000; Nadeau et al. 2002; D. Anderson 2006) using different datasets. 
as a salient electoral issue. Finally, this article expects that the positive effects of economic growth on incumbent voting will disappear when government corruption severely deteriorates because, as one issue becomes more salient, the other is less likely to be salient.

In addition to testing these hypotheses, this paper also contributes to the existing literature by using averaged economic indicators during the incumbent government's ruling period instead of election-year economic indicators. It is conventional wisdom that the economic evaluations of voters are primarily made based on election-year economic indicators. Therefore, previous studies ignored the possibility that voters would evaluate the economic performance of the incumbent government in terms of the performance of the government's entire period of rule, not merely the performance during the election year. However, indeed, the incumbent government is responsible not only for economic conditions during the election year and the year before, but also for the economic condition of the entire period it is in power. Therefore, if a government achieved tremendous economic prosperity in its first two or three years but failed to do so in the last year of its reign, or vice versa, do voters reward or punish the incumbent government? If voters are rational, they may decide by making evaluation based not only on the performance of the government's latest year, but rather its entire time in office.

On this matter, Healy and Lenz (2014) recently found that the reason why voters rely on election-year economic performance is due to limited information about the economy. They found that voters were more likely to evaluate presidents on cumulative economic performance if those voters were provided with enough information. In this regard, due to the development of the Internet and increases in education levels across countries, voters more recently might be exposed to massive amounts of information more easily and cheaply than in the past. Therefore, it can be expected that contemporary voters are more likely to use comprehensive evaluations of economic situations compared to voters in the past. Due to the fact that this paper deals with recent elections from 1996 to 2012, there is an expectation that voters care not only about electionyear economic indexes, but also averaged economic performance during the entire ruling period of an incumbent government. It was found that incumbent vote shares were much more affected by averaged GDP per capita growth than election-year GDP per capita growth. For this reason, this paper uses the average of GDP per capita growth between the previous election and the current election to test the main hypotheses of this paper. ${ }^{2}$

${ }^{2}$ Krause and Méndez (2009) also used the average of GDP growth, inflation, and unemployment between the previous and the current elections. 
To test these hypotheses, this article examines 92 election outcomes from 41 countries between 1996 and 2012 in developed and developing countries. The results bolster the theoretical expectations of this article. According to the results, the effects of economic growth on incumbent vote shares disappear as the absolute level of GDP per capita increases. Also, the effect of the change in the incumbent government's level of corruption on incumbent vote shares disappears as the absolute level of government corruption increases. Finally, the effect of economic growth on incumbent vote shares becomes statistically meaningless as the government's corruption level grows, while the effect of a government's corruption growth has a statistically significant impact on incumbent vote shares only when economic growth is moderate. Thus, the findings of this article show that economic voting and corruption voting have an inversely proportional relationship, and implies that when one issue becomes more volatile, it dominates other issues in elections.

\section{ISSUE SALIENCE AND CONDITIONAL RETROSPECTIVE VOTING}

The standard retrospective voting theory is simple: "Voters judge retrospectively... [and] may reject what they have known; or they may approve what they have known" (Key 1966, 61). That is, citizens vote for the incumbent government if they think the incumbent is doing all right; otherwise, they vote against it. To test this standard retrospective voting theory, particularly in terms of the government's economic performance and accountability, many empirical studies have been conducted in the United States and other advanced industrialized countries, but the magnitude and nature of economic voting across elections have varied over time and from country to country (Paldam 1991; Lewis-Beck and Stegmaier 2000; Duch and Stevenson 2006, 2008; Krause and Méndez 2009; Klanšnja and Tucker 2013). However, it is not surprising that retrospective voting varies according to different institutional and socioeconomic circumstances because retrospective voting is based on voters' rational evaluations of government performance (Fiorina 1981). According to rational choice theories, "institutions, so defined, structure the individual choices of strategic actors so as to produce equilibrium outcomes" (Levi 1997, 25). Thus, the strategies of rational actors are heavily influenced by their institutional and socio-economic environments, and so their decisions vary according to those circumstances.

Among the various conditions affecting the voting behaviors of rational 
actors, the salience of issues is considered one of the most powerful ones structuring the rational decisions of voters (Shapiro 1969; Rabinowitz et al. 1982; Krosnick 1988; Lavine et al. 1996). There are often many different relevant issues in an election, and voter choice often depends on those several issues taken collectively (Stokes 1963). In other words, voters basically do not face unidimensional choices but rather multidimensional ones. However, as Sartori (1976) argued, even though there are many different issues and cleavages, it is almost impossible-if not irrational-for voters to take all of them into consideration because "when the voter is confronted with five or more practices, the information costs and the indeterminacies multiply exponentially, and some drastic simplification becomes a sheer necessity" (Sartori 1976, 341). Voters usually make their decisions based on the salience of issues (Budge 1999); thus, when one issue becomes more salient to voters, the importance of other issues is more likely to diminish. Using spatial voting models, Kadane (1972) and Kramer (1972) proved that if voters have to make a decision over a set of issues in an n-dimensional space, issue salience can have a great impact on the outcome. Empirical research in political psychology found that the extent to which issues are personally salient determines the cognition of voters and their political behaviors concerning policy outcomes (Lavine et al. 1996). That is why political parties tend to selectively emphasize issues where they feel they have a good reputation (Budge and Farlie 1983; Petrocik 1996; van der Brug 2004) and try to make those issues more salient to voters during the election.

Therefore, economic voting is expected to be more salient when the health of the economy is an especially salient issue, and the same can be said of corruption voting. The idea of conditional retrospective voting is that standard economic voting and corruption voting have stronger or weaker influence under specific circumstances. Therefore, it is reasonable that conditional retrospective economic and corruption voting should be examined based on what conditions determine whether the economy or corruption become more or less salient to voters. This is because the magnitude of economic and corruption voting is determined by the conditions that make the economy and corruption salient. Singer (2011b) found that the salience of the economy differs according to countries, and over time within a country. Therefore, "variations in the economy's salience need to be further incorporated into studies linking economic and political outcomes" (Singer 2011b, 284).

\section{THE ECONOMY, CORRUPTION, AND CONDITIONAL VOTING HYPOTHESES}


As mentioned above, the strength of economic and corruption voting is determined by the conditions that make the economy and corruption more salient. In the literature on economic and corruption voting, researchers found that the issue salience of the economy is affected by the level of national wealth or the extent of a country's welfare systems (Radcliff 1992; Pacek and Radcliff 1995; Aguilar and Pacek 2000; Singer 2011b), and the issue salience of corruption is influenced by the extent of government corruption and the country's economic situation (Singer 2011b; Klanšnja and Tucker 2013).

First, the issue salience of the economy is stronger in poorer countries than in wealthier ones, and for economically insecure populations more than for richer voters (Radcliff 1992; Aguilar and Pacek 2000; Singer 2011b) because people in poor countries are more likely to be vulnerable to economic fluctuations. "In a situation where the level of economic attainment has reached the point where the socio-political system has significant cushions against minor economic perturbations, and where, as a result of that fact, many citizens may tend to be more politically sensitive to other than strictly economic issues, it may be that the economy has less of an impact on the decision to vote" (Radcliff 1992, 445). Similarly, Inglehart $(1971 ; 1997)$ found that people who live in wealthy states with strong social safety nets were more likely to be more politically motivated by non-materialist rather than materialistic values compared to people who lived in less developed countries. Inglehart (1997) argued that the new era of postmodernization has led voters to shift away from maximizing economic gains to newer values after the need for security and economic stability had been fulfilled.

Moreover, in wealthy countries even voters classified as alow income group were less likely to suffer from poverty or economic hardship compared to their counterparts who live in less-wealthy countries. In addition, most wealthy countries-except a few oil-rich states-have relatively well-organized welfare systems to protect people from bad economic situations. Therefore, high levels of economic development and welfare tends to reduce voters' incentives to base their votes on economic conditions. Singer (2011a) found that by reducing vulnerability to poverty, strong welfare programs lower the issue salience of the economy and consequently help incumbents to stay in power during economic downturns. Moreover, economies in wealthy countries are relatively stable compared to less-wealthy countries; therefore, voters in those wealthy countries tend to be less impacted by changes in the economy. In contrast, economic issues are more salient in poorer democracies than in wealthy democracies because the economy tends to dominate other issues when economic conditions are unstable, 
in decline, or underdeveloped (Singer 2011b). ${ }^{3}$ Moreover, the working and lower classes in less-wealthy countries react more sensitively to macroeconomic fluctuations because of their higher personal stakes (Aguilar and Pacek 2000).

Based on this rationale, it is not surprising to argue that the economy is more salient in poorer countries than in economically developed countries. In addition, according to issue salience theory, issue salience determines the electoral results. In other words, if an issue is not salient in a given election, the issue cannot affect the electoral results. Therefore, citizens in poorer countries are more likely to vote based on economic conditions than voters in economically developed countries, and there is an expectation that this tendency will weaken as the wealth of a country increases because the economy will be a less salient issue at election time. It is expected that the effects of macroeconomic conditions on incumbent electoral outcomes will disappear as the wealth of a country increases.

Hypothesis 1: The effect of economic growth on the vote share for an incumbent party will be positive, but the effect will weaken as the wealth of a country increases.

Second, corruption is also widely considered one of the more salient issues affecting voters' considerations when evaluating incumbent performance (Welch and Hibbing 1997; Anderson and Tverdova 2003; Krause and Méndez 2009; Klašnja and Tucker 2013). Regarding country specific studies of corruption voting, Welch and Hibbing (1997) found that, in general, there was a negative relationship between charges of corruption against an incumbent and that incumbent's share of the vote in U.S. congressional elections. In addition, Slomczynski and Shabad (2011) explored whether the voters' perception of corruption of a particular party influenced voting intentions in Poland. They found that a voter's intention to vote for a particular party decreased according to the increase in his/her perception of how corrupt was that party. On the other hand, Klašnja and Tucker (2013) examined corruption voting under two different conditional circumstances: the level of corruption and the state of the economy. By comparing a highly corrupt country (Moldova) to a less corrupt country, Klašnja and Tucker (2013) found that voters punished incumbents for corruption regardless of the state of the economy in a low corruption country, whereas voters punished incumbents for corruption only when the state of

3 By analyzing CSES survey data sets, Singer (2011b) found evidence supporting the hypothesis that the issue salience of the economy is stronger in poor countries and weaker in wealth countries. 
the economy was also poor in a high corruption country. In turn, Krause and Méndez (2009) recently conducted research on the relationship between corruption and the incumbent vote share across countries. They found that corruption in public office was effectively punished by voters, and it remained significant even when they tested it against economic variables. Therefore, corruption voting was detected across various countries.

However, similarly to the case of economic voting, corruption voting has not been examined in terms of the relationship between the absolute level of government corruption and the magnitude of corruption voting. Using the same logic as applied to the salience of the economy, people were less likely to care about the level of government corruption if they believed that their government was accountable because their desire for having an accountable, corruption-free government already had been achieved. As Maslow (1954) and Inglehart (1997) argued, people did not aspire to what they were already satisfied with. According to Maslow (1954), people's needs have a hierarchical order, and if one need was satisfied, people were less likely to pay attention to that need. Therefore, corruption will be a salient issue when the government is seen as highly corrupt since the need of people for having government accountability is still not satisfied in that society. Furthermore, corruption will be a less salient issue when the government is seen as trustworthy because of the opposite reason. Singer (2011b) found empirical evidence for this expectation-corruption is more salient where the incumbent government is more corrupt than where the government is more transparent.

Theoretically, however, the opposite argument could be made. Corruption would be a much more salient election issue when a country had low levels of corruption. In corruption-free countries, citizens may have very high expectations for their politicians in terms of honesty and integrity. These high expectations may make the citizens very responsive to politicians who use their offices for person gain. Following this rationale, the effect of the change in perceptions of corruption on vote choice and electoral outcomes would be stronger in light of political reforms, although there is the possibility that there is no correlation between corruption performance voting and levels of corruption in a country. Since corruption is a valence issue, and no one likes corrupt politicians, voters may punish tarnished politicians regardless of how clean is the political system overall.

Unfortunately, no empirical study has attempted to figure out how the absolute level of corruption affects the electoral fortunes of incumbent parties. Therefore, it is worth examining whether the absolute level of corruption affects the magnitude of corruption performance voting. Assuming that corruption voting 
will be stronger in high-corruption countries and weaker in low-corruption countries:

Hypothesis 2: The effect of growth in perceived corruption of a government on the incumbent party's vote share will be negative, but the effect will be weaker if the absolute level of government corruption is low.

Finally, although numerous studies have examined economic voting and corruption voting, with the exception of Klašnja and Tucker's (2013) none have examined the relationship between economic voting and corruption voting simultaneously. Moreover, while Klašnja and Tucker (2013) found interaction effects of the economy and corruption on vote choice, their research was limited to only two countries, Sweden and Moldova. This article will more extensively explore the relationship between economics and corruption in voting.

On one hand, according to the theories of issue salience and voting, voters tend to make decisions based on the salience of issues. Moreover, voters are apt to pay less attention to an issue when they perceive other issues as more salient. In terms of the relationship between corruption and the economy, since corruption is a competing issue with the economy in elections, if corruption becomes more salient, the economy should be less salient. On the contrary, when economic conditions are bad, corruption is more likely to be perceived as less important. Therefore, when the salience of corruption increases, economic issues are less likely to affect vote choice because the high salience of corruption will mitigate the attention of voters on the economy (Singer 2011b).

On the other hand, several scholars have argued that voters tolerated corrupt politicians when economic conditions were good (Pereira et al. 2009). Thus, positive economic conditions mitigated the impact of perceptions of corruption on presidential approval ratings, whereas negative economic conditions magnified the negative effect of corruption (Zechmeister and Zizumbo-Colunga 2013). This is called a trade-off hypothesis. Empirically, however, the results for this argument have been mixed. In particular, some find that economic growth neither intensifies nor attenuates the impact of corruption on presidential approval (Rosas and Manzetti 2015).

Thus, there are several competing hypotheses to explain the effects of economic conditions on corruption voting. In this paper, I expect that the effect of economic growth on incumbent vote share will be weaker when voters perceive that the level of corruption in the incumbent government increases. In the same vein, the effect of perceived corruption on incumbent vote share 
will be weaker when voters perceive that economic conditions have severely deteriorated. This was because, as Sartori (1976) and Budge (1999) have argued, voters tended to focus on the most salient issue when making a vote choice even though they might have been confronted with several important issues. Following this rationale:

Hypothesis 3: The effect of the economy on the incumbent party's vote share will decrease when a change in the perception of corruption increases, whereas the effect of the change of perceived corruption on the incumbent party's vote share will weaken when economic conditions worsen (GDP per capita growth decreases).

\section{RESEARCH DESIGN}

To test the hypotheses, I analyze 92 elections in 41 democratic countries between 1996 and 2011. Although an effort was made to collect data from as many countries and electoral periods as possible, the sample was restricted by the availability of corruption data, which was one of the main independent variable examined in this paper. Nevertheless, unlike most of the extant literature, such as Lewis-Beck and Mitchell (1990), Paldam (1991), Powell and Whitten (1993), Whitten and Palmer (1999), and Nadeau et al. (2002), which focused mainly on Western democracies, this paper included elections from nonWestern democracies as well as from Western countries. ${ }^{4}$ The unit of analysis is incumbent party electoral success. The elections examined in this paper were presidential elections in presidential systems and parliamentary elections in parliamentary systems because voters were more likely to attach greater accountability for government policy to the dominant branch of government (Tucker 2006; Hellwig and Samuels 2007). Thus, choosing dominant-branch elections increased the reliability of the results. For mixed systems, I also chose elections of the dominant branch (i.e., parliamentary elections under cohabitation and presidential elections under unified governments in France). For executive elections, I used results from the first or only round of elections. In turn, the reason I chose the time period from 1996 to 2012 was that one of the main independent variables, a country's perceived corruption index (CPI) score, was only available from 1995. All sources are summarized in Appendix B.

4 The list of democracies analyzed in this paper is in Appendix A. 
The dependent variable is the change in voting for the incumbent party from the previous election for either the president or prime minister. In previous studies, researchers used one of the two different dependent variables: the gain or loss of the incumbent party vote share (Powell and Whitten 1993) or the percentage of the incumbent party's vote share using a control variable that was a lagged vote share for the incumbent party (Whitten and Palmer 1999; Hellwig and Samuels 2007). Previous studies have argued that if one includes the lag of vote share as a control variable, the percentage share of the vote for the incumbent government results in similar outcomes to that of the vote change of the incumbent party (Whitten and Palmer 1999). I also tested models with the two different dependent variables and got the same results for the significance levels and directions of coefficients. Additionally, there is one more complication for the dependent variable because the data include many parliamentary elections conducted under coalition governments. There are two ways to measure the vote share of the incumbent government when there is a coalition government. On one hand, we can measure the vote share of all parties that constitute the coalition government. On the other, we can measure the vote share of only the prime minister's (the largest) party in the coalition government. The latter is used for analysis in this paper because voters do not always reward or punish all parties in a coalition government in the same way (Anderson 1995; Debus, Stegmaier, and Tosun 2014). Thus, it is not proper to assume that all parties in a coalition government have the same electoral fortune related to economic success or failure. Moreover, the prime minister is also usually the main target of blame or praise for economic performance (Lewis-Beck 1997). For these reasons, this paper uses the vote share of only the prime minister's party in the coalition government.

The main independent variables are the average growth in GDP per capita and the change in perceived government corruption (CPI Index) between the year prior to the election and the election year. ${ }^{5}$ Even though there are several macroeconomic indexes affecting incumbent vote shares, real annual GDP per capita growth is considered the most important and consistent macroeconomic index to determine the electoral fortunes of incumbents (Powell and Whitten 1993).

Unlike other studies using aggregate-level data, this paper measures the average rate of change in the economic variables between the previous and current elections. Many studies of economic voting assume that voters are

5 I originally planned to use the change in CPI between the previous and current election years. However, CPI was only first measured in 1995. 
influenced more by recent changes than by those more long-term (Powell and Whitten 1993; Whitten and Palmer 1999; Lewis-Beck and Stegmaier 2000). However, some have a different perspective on this matter. Notably, Hibbs (1987) claimed that voters considered economic growth over the entire term of office even though they place more weight on the latest economic conditions. Following this argument, I use an alternative economic measurement because retrospective economic voting could be based on the entire performance of the incumbent government, not only on recent economic conditions. In most cases, incumbent governments hold office more than three years, so they are responsible for the economic condition of the election year as well as that of the year before. Thus, appropriate evaluation of the economic performance of the incumbent government should not be a comparison of the economic conditions between the year prior and the current election year, but rather should be about the economic conditions of the incumbent government's entire term of office. There is some empirical evidence for this argument. For example, Wlezien and Erikson (1996) found that cumulative per capita income growth was highly correlated with presidential approval in the United States. In addition, analyzing U.S. presidential elections between 1952 and 2012, Wlezien (2015) revealed that voters did not react only to very late economic conditions, but they equally considered the conditions of the last two or three years of a presidential term. Outside the U.S. context, Healy et al. (2016) conducted a representative election survey in Sweden and found that Swedish voters were not myopic but considered the entire income growth over the administration's term of office.

Moreover, Healy and Lenz (2014) found evidence that voters were more likely to consider the performance of the entire incumbent's term rather than only election-year performance when they were provided with more accessible and detailed information. Since the development of the Internet and increases in education levels across countries, voters are now more exposed to massive amounts of information that can be relatively easily and cheaply accessed compared to in the past. Therefore, it can be expected that voters today are more likely to use comprehensive information to evaluate economic performance when making voting decisions.

With respect to the corruption variable, this paper uses corruption perception measures-the CPI index-to capture the level of corruption of each country. ${ }^{6}$ The CPI is defined as "an index that draws on multiple expert opinion surveys

6 Since 1995, the CPI index has been reported by Transparency International Organization (http://www.transparency.org). The index ranges on a scale from zero, indicating high levels of perceived corruption, to ten, indicating low levels of perceived corruption. 
that poll perceptions on public sector corruption" and the corruption of politicians (Transparency International 2006). However, the CPI has been most widely used by those who have studied corruption voting across countries (Herzfeld and Weiss 2003; Persson et al. 2003; Krause and Méndez 2009) under the assumption that "CPI are likely to be highly correlated with the local voters' perceptions" (Krause and Méndez 2009, 181). Thus, the CPI can be a good proxy variable for voter perception about the level of corruption in the incumbent government. To examine the hypotheses, based on the formula of Krause and Méndez (2009), I used a "perceived corruption increase" (PCI) index to measure whether perceived corruption had increased during the incumbent's term of office. Specifically, Krause and Méndez define PCI as " $-($ CPI t+e - CPI t ), where $t$ represents time (in years) and e represents the number of years between elections. Thus, a positive value for PCI corresponds to a perceived increase in corruption, while a negative value corresponds to a perceived decrease in corruption" (Krause and Méndez 2009, 186).

In addition, as control variables, this paper includes two other macroeconomic indicators: the average inflation rate and unemployment growth rate between the previous election and the more recent election because inflation and unemployment are also considered important economic indexes affecting incumbent vote shares (Powell and Whitten 1993; Whitten and Palmer 1999; Stevenson and Vavreck 2000; Hellwig 2012).

For model specification, this paper uses random effect regression models with robust standard errors clustered by country because the variables are crosssectional and time-series. ${ }^{7}$ When using pooled OLS with data, including crosssectional and time-series, there is the possibility of violating the Gauss-Markov assumptions that the error terms have constant variance and are not correlated (Stimson 1985; Whitten and Palmer 1999). Thus, to avoid this violation, I used robust standard errors clustered by country.

\section{RESULTS}

One of main purposes of this paper was testing whether incumbent parties were punished or rewarded for the average of GDP per capita growth, inflation, and unemployment between previous elections and more recent elections, not just

7 Hausman tests were used to decide which models were more appropriate for my dataset between fixed and random effects models because my dataset was cross national time-series data. According to the results of the Hausman tests, I selected random effects models. 
for those indexed for the election year. Thus, I estimated and compared the two models to figure out which macroeconomic indicators had greater effects on incumbent vote shares between the economic indicators of the current election year and the effects of the average indicators of an incumbent's entire term of office.

Table 1. Comparing the Effects of the Election Year Economic Indicators to those of Averaged Economic Indicators of Entire Incumbent Years on the Incumbent Party's Vote Change

\begin{tabular}{lcc}
\hline & $\begin{array}{c}\text { Model 1 } \\
\text { (Election } \text { Year Indicators) }\end{array}$ & $\begin{array}{c}\text { Model 2 } \\
\text { (Averaged Indicators) }\end{array}$ \\
\hline GDP Growth & .757 & $2.704^{* * *}$ \\
& $(.638)$ & $(.547)$ \\
Inflation & $-.176^{* *}$ & $-.136^{* * *}$ \\
Unemployment & $(.089)$ & $(.035)$ \\
& -.032 & .205 \\
Corruption Growth & $(.135)$ & $(.164)$ \\
& $-3.363^{* *}$ & $-2.941^{* * *}$ \\
Constant & $(1.398)$ & $(1.079)$ \\
Obervations & $-4.364^{* *}$ & $-10.323^{* * *}$ \\
$\boldsymbol{R}^{2}$ within & $(2.191)$ & $(2.222)$ \\
$\boldsymbol{R}^{2}$ between & 92 & 92 \\
$\boldsymbol{R}^{2}$ overall & 0.015 & 0.174 \\
& 0.338 & 0.443 \\
\hline
\end{tabular}

Note: DV: the change of incumbent party's vote share between current and previous elections. The robust standard errors are in brackets. ${ }^{*} \mathrm{p}<0.10,{ }^{* *} \mathrm{p}<0.05,{ }^{* * *} \mathrm{p}<0.01$.

For model 2, GDP per capita growth, inflation, and unemployment are averaged GDP per capita growth, averaged inflation rate, averaged unemployment rate of entire incumbent periods, respectively.

Table 1 demonstrates the general effects of the economy and corruption on incumbent vote shares using two models. Model 1 tested the effects of GDP per capita growth, inflation rate, and unemployment rate for the election year ${ }^{8}$ on incumbent vote shares, whereas Model 2 tested the effects of the average of GDP per capita growth, inflation, and unemployment between the previous and more recent elections on the incumbent party's vote share. All models use

8 If the election was held after July, I included the election year's economic indexes, whereas if the election was held before July, I included the economic indexes of a year before the election. 
the change in incumbent vote share as the dependent variable. In Model 1, GDP per capita growth, which is the main economic variable used in the economic voting literature, is not statistically significant even at a $90 \%$ significant level, while in Model 2, average GDP per capita growth shows statistical significance and substantive effects on incumbent vote share. In addition, the unemployment rate is also not statistically significant in either model. However, the inflation rate is statistically significant, as well as having an expected (negative) sign of coefficient in both models. ${ }^{9}$ In turn, the corruption variable PCI is statistically significant and shows expected sign (negative) in both models. That is, as the level of perceived corruption increases, the incumbent party loses more votes.

Overall, Model 2 shows a stronger relationship between macroeconomic indicators and incumbent vote share because of Model 2 (.258) is much greater than that of Model 1 (.095), as well as more macroeconomic indicators having statistically significant effects on incumbent vote share in Model 2. This result shows that voters evaluate the incumbent's performance not only based on election-year performance but also even more strongly based on the incumbent's performance during the entire term of office. Hence, by using averaged economic indicators, I estimated random effects regressions of the incumbent party's vote change in the sample countries. Table 2 shows the regression results from the three models.

First, Model 3 tests Hypothesis (1) that the effect of economic growth on vote share for incumbent parties will be positive, but this tendency will weaken as the wealth of a country increases. To test this hypothesis, the interaction term between GDP per capita growth and GDP per capita was included in Model 3 because GDP per capita showed the absolute level of wealth of a country. In Model 3, GDP per capita growth had a positive and statistically significant coefficient. However, the interaction term between GDP per capita growth and GDP per capita showed a negative and statistically significant coefficient. This implies that the positive effect of GDP per capita growth on an incumbent party's vote share decreases as the absolute level of GDP per capita of a country increases. Therefore, the sign and significance level of the interaction term are supportive of the hypothesis. It supports my expectation that voters in lesswealthy countries are more likely to reward and punish incumbent parties for generating high or low rates of economic growth than those in wealthy countries.

Second, Model 4 shows the estimated regression results to test Hypothesis

9 Unlike GDP growth per capita, a higher or positive number for the unemployment and inflation rates represents a bad economic situation. Thus, the relationship between unemployment and inflation rates and incumbent vote shares should be negative if economic voting is meaningful. 
(2) that the effect of the growth in perceived government corruption on the incumbent party's vote share will be negative, but the effect will be weaker if the absolute level of government corruption is high. To test the hypothesis, I included the interaction term between the change of perceived corruption index (PCI) and the absolute level of perceived corruption (CPI: Corruption Perceived Index). Model 4 shows that a change in the perceived corruption index (PCI) has a negative and statistically significant coefficient, whereas the sign of the interaction coefficient is positive. It supports the expectation of Hypothesis (2) that the incumbent party is punished by voters when their corruption level increases, but an increase in the corruption level does not hurt incumbent parties when the absolute level of government corruption is high.

Table 2. Economic Growth, Corruption, and the Incumbent Party's Vote Change

\begin{tabular}{lccc}
\hline & Model3 & Model4 & Model5 \\
\hline GDP Growth & $4.176^{* * *}$ & $2.733^{* *}$ & $2.735^{* * *}$ \\
GDP & $(.649)$ & $(.559)$ & $(.522)$ \\
GDP Growth X GDP & $.001^{* * *}$ & & \\
& $(.0001)$ & & \\
Inflation & $-.001^{* * *}$ & & $-.140^{* * *}$ \\
& $(.00003)$ & & $(.036)$ \\
Unemployment & $-.087^{* *}$ & $-.100^{* *}$ & .168 \\
& $(.040)$ & $(.039)$ & $(.165)$ \\
Corruption Growth & $.365^{* *}$ & .298 & -.928 \\
& $(.171)$ & $(.190)$ & $(1.919)$ \\
Corruption Level & $-2.621^{* *}$ & $-8.842^{* *}$ & \\
Corruption Growth X Corruption & $(1.062)$ & $(4.365)$ & \\
Level & & .390 & \\
GDP Growth X Corruption Growth & & $(.341)$ & -1.100 \\
& & 1.104 & $(.861)$ \\
Constant & & $(.731)$ & $-10.154^{* * *}$ \\
Obervations & & & $(2.260)$ \\
$\boldsymbol{R}^{2}$ within & $-16.300^{* * *}$ & $-13.413^{* * *}$ & 92 \\
$\boldsymbol{R}^{2}$ between & $(3.781)$ & $(4.332)$ & 0.178 \\
$\boldsymbol{R}^{2}$ overall & 92 & 92 & 0.443 \\
\hline
\end{tabular}

Note: DV: the change of the incumbent party's vote share between current and previous elections. The robust standard errors are in brackets. ${ }^{*} p<0.10,{ }^{* *} p<0.05,{ }^{* * *} p<0.01$.

Last, Model 5 tests Hypothesis (3) that the effect of the economy on the 
incumbent party's vote share will be weaker when perceived government corruption increases, whereas the effect of perceived government corruption on the incumbent party's vote share will weaken when the economy is getting worse. To test this hypothesis, Model 5 includes the interaction term between GDP per capita growth and the change of perceived corruption (PCI). The result of Model 5 illustrates that GDP per capita growth has a positive and significant effect on incumbent vote share and corruption growth has a negative effect, whereas the interaction term has a negative coefficient.

However, making inferences about interaction terms between two continuous variables using only the coefficient is rather limited. Recently, several studies (Braumoeller 2004; Brambor, Clark, and Golder 2006; Berry, Golder, and Milton 2012) have pointed out that when one estimates the conditional hypotheses, interaction terms and their constitutive variables must be included in the model. Thus, conditional hypotheses should be interpreted with a marginal effect graph. For that reason, this paper presents the marginal effect graphs for the interaction term for each model.

Figure 1. Marginal Effect of GDP per capita Growth on the Change of Governing Party Vote Share Conditional on GDP per capita Level $(95 \% \mathrm{Cl})$

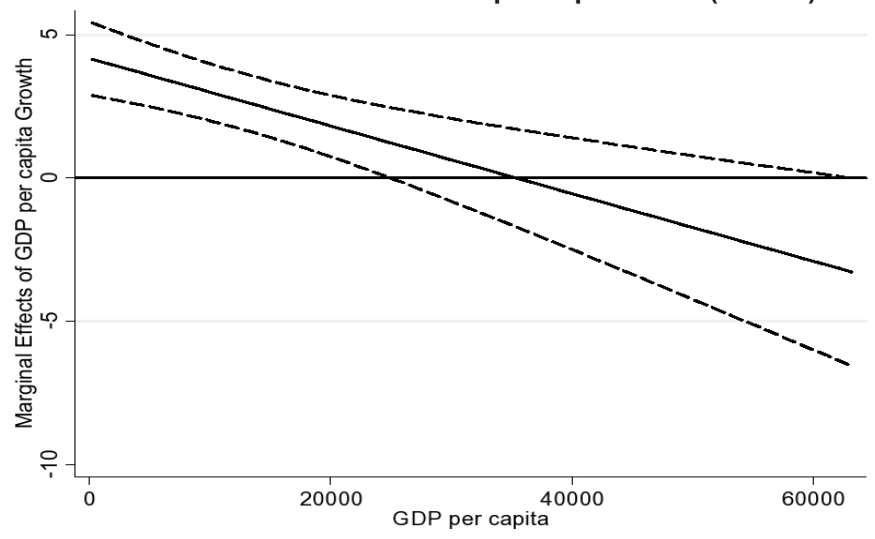

Figure 1 demonstrates the marginal effect of GDP per capita growth on the vote share of the incumbent party conditional on GDP per capita. The marginal effect of GDP per capita growth on the vote share of the incumbent party is positive and statistically significant, but its effect decreases as the GDP per capita of a country increases. Moreover, the effect of GDP per capita growth on the 
incumbent party's vote share disappears after the GDP per capita of a country goes over around US \$2,500. This result is supportive of Hypothesis (1) that the positive relationship between economic growth and the incumbent party's vote share will weaken and disappear as the absolute level of wealth of a country increases.

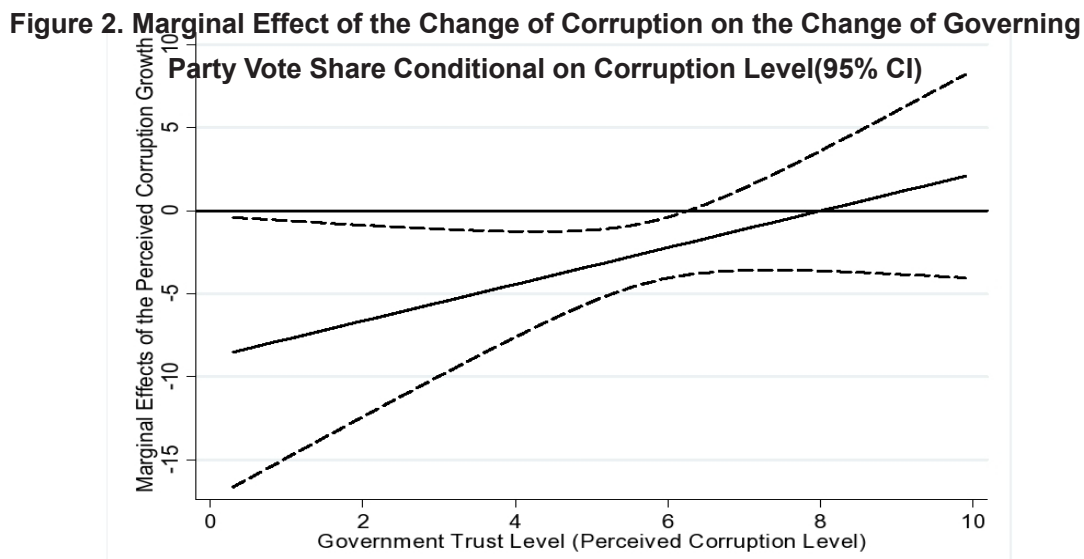

Figure 2 demonstrates the marginal effect of the perception of government corruption growth on the vote share of the incumbent party conditional on the absolute level of perceived corruption. The marginal effect of perceived corruption growth on the vote share of the incumbent party is negative and statistically significant, but its effect decreases as government trust levels increase, which means that the perceived corruption level decreases. In the perceived corruption level (CPI), higher scores indicate more accountability and less corruption. Furthermore, the effect of perceived corruption growth on the incumbent party's vote share disappears when the absolute level of perceived corruption (level of government trust) is greater than around 7, which indicates a low level of corruption. This result bolsters Hypothesis (2) that the negative relationship between corruption growth and incumbent party's vote share will weaken and disappear as the absolute level of corruption of a country decreases. 
Figure 3. Marginal Effect of GDP per capita Growth on the Change of Governing Party Vote Share Conditional on the Change of Corruption (95\% Cl)

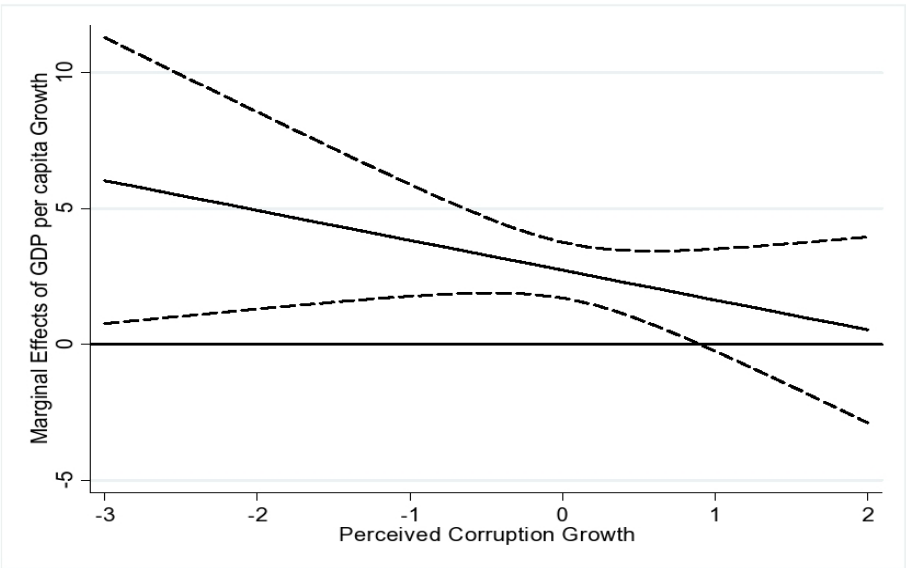

Figure 3 shows the marginal effect of GDP per capita growth on the vote share of the incumbent party conditional on the change of perceived corruption. The marginal effect of GDP per capita growth on the vote share of the incumbent party is positive and statistically significant, but its effects decline as the change in perceived corruption increases. In other words, when voters perceive that incumbent governments have become more corrupt, voters were less likely to be concerned about their economic performance. Specifically, when perceived government corruption increased by more than one level out of 10, GDP per capita growth did not have statistically significant effects on the incumbent party's vote share. This result confirms the expectation of Hypothesis (3) that the positive relationship between economic growth and the incumbent party's vote share will weaken and disappear when perceived corruption growth increases because corruption becomes a more important issue than the economy in a given election. 
Figure 4. Marginal Effect of the Change of Corruption on the Change of Governing Party Vote Share Conditional on GDP per capita Growth (95\% Cl)

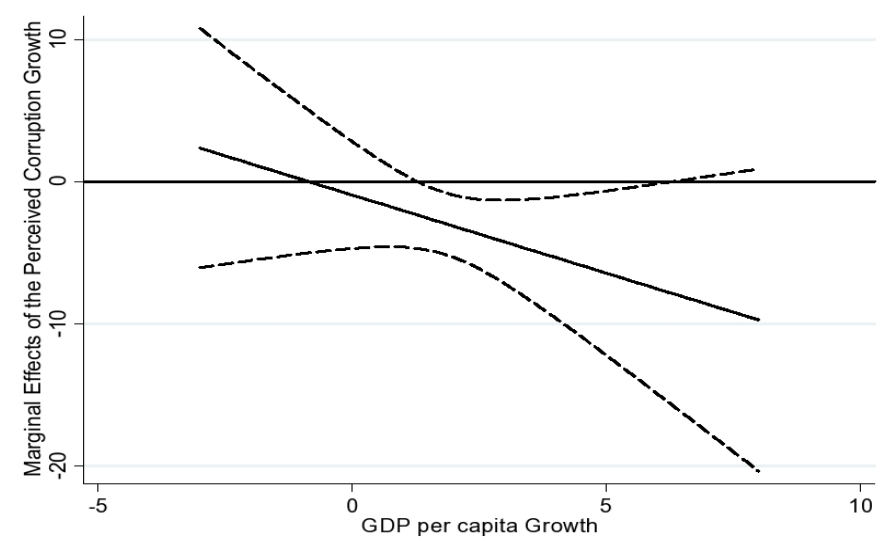

Figure 4 illustrates the marginal effect of perceived corruption growth on the vote share of the incumbent party conditional on the change of GDP per capita growth. Hypothesis (3) predicted that the marginal effect of perceived corruption growth on the vote share of the incumbent party will be negative, but its effect goes down as GDP per capita growth decreases because the most salient issue for voters tends to be the economy when the economy is bad. Figure 4 shows that the marginal effect of perceived corruption growth on the vote share of the incumbent party is negative and statistically significant only when GDP per capita growth is between zero and seven percent. This implies that voters are less likely to care about government corruption if the economy is bad or very good. Overall, Figures 3 and 4 provide evidence supporting Hypothesis (3). Specifically, the effect of the economy on the incumbent party's vote share will decrease as the perceived corruption growth increases, whereas the effect of the perceived corruption growth on the incumbent party's vote share will weaken as the economic growth decreases.

\section{CONCLUSION}

The economic conditions of a country and levels of corruption of its government have been considered as two of the most significant criteria to predict the success of incumbent parties in elections. According the literature on economic voting 
and corruption voting, when economic conditions are bad and the government becomes more corrupt, voters tend to punish the incumbent government. However, this does not always happen, and the strength of the relationship between economic conditions or government corruption and the electoral success of incumbent parties varies across elections. Why does the strength of that relationship vary and under what conditions will the strength of that relationship become weaker or stronger? This paper provides an answer to these questions. The key to solving the qestioned is the issue salience of the economy and corruption. According to Singer (2011b), the economy becomes more salient as an election issue in poor countries or when the economy has gotten worse, and corruption becomes a more salient election issue when corruption is extensive or where the government has become more corrupt. Furthermore, the economy becomes a less salient issue when other competing issues, such as corruption or human rights, become more salient.

Based on this empirical foundation, this study builds three new conditional retrospective voting hypotheses and finds evidence supporting all of them. First, in terms of the effects of economic growth on the vote share of incumbent parties, the results of this paper show that the effect of economic growth decreases as the level of national wealth increases. This implicitly supports the idea that people who are in vulnerable economic conditions are more likely to engage in economic voting (Fossati 2014). Therefore, in general, voters who live in wealthy countries are less likely to be concerned with the economy than those who live in relatively poor countries because there are more economically vulnerable people in less wealthy countries. Second, when it comes to the effect of perceived corruption change on the incumbent party's vote share, the effect of perceived corruption change decreases as the absolute level of government corruption decreases. This result implicitly means that voters are more sensitive to a change in government corruption where voters perceive their government already is very corrupt. Third, the effect of economic growth on the incumbent party's vote share decreases as voters perceive that their government becomes more corrupt, whereas the effect of perceived corruption change on the incumbent party's vote share is only significant when there is little change in economic growth. This result indicates that when the economy experiences great progress or severe hardship, voters mainly pay attention to the economy, but when there is not so much change in the economy then voters turn their attention to other issues such as corruption. In turn, when other issues such as corruption become more problematic, voters' attention to the economy decreases. Finally, this paper found that averaged real GDP per capita growth had a significant effect on incumbent vote shares. In previous studies, conventional wisdom indicated 
that voters mainly paid attention to the economic situation of election years, or the year prior, rather than the comprehensive economic situation of the incumbent's entire term of office when those voters evaluated the incumbent's economic performance. However, the results of this paper show the possibility that voters might factor in the economic performance of entire term of an incumbent administration or leader when casting votes. Recently, Healy and Lenz (2013) found that voters actually tended to evaluate presidents based on cumulative growth when enough information was provided to them. In today's environment, with the development of the Internet and increasing education levels, people have easier access to more information about the economy. This situation encourages voters to use cumulative economic performance to make voting decisions.

In that regard, this study makes contributions to the existing literature on economic voting. First, unlike most previous studies that used macroeconomic indicators of the election year or comparative indicators, this paper used the average of real GDP per capita growth, inflation, and unemployment over the duration of the electoral cycle. By using averaged macroeconomic indicators, one can examine whether voters were rational enough to evaluate the incumbent government according to its whole performance or were impetuously distracted by short-term economic effects. The results reveal that voters' evaluations of the performance of the incumbent government were based on the government's entire term of office, as well as the short-term effects of the election year. Second, this study incorporated the political issue of corruption into an economic voting model in order to examine how economic voting behaviors were affected by competing political issues. The results showed that economic voting became weak when other competing issues became worse. Moreover, this research found that corruption voting also was contingent on the issue salience of corruption as well as other competing issues, such as the state of the economy.

\section{REFERENCES}

Anderson, Cameron D. 2006. "Economic Voting and Multilevel Governance: A Comparative Individual-Level Analysis." American Journal of Political Science 50(2), 449-463.

Anderson, Christopher J. 1995. "The Dynamics of Public Support for Coalition Governments." Comparative Political Studies 28(3), 350-383. . 2000. "Economic Voting and Political Context: A Comparative Perspective." Electoral Studies 19(2-3), 151-170. 
. 2007. "The End of Economic Voting? Contingency Dilemmas and the Limits of Democratic Accountability." Annual Review of Political Science 10, 271-296.

Anderson, Christopher J. and Yuliya V. Tverdova. 2003. "Corruption, Political Allegiances, and Attitudes toward Government in Contemporary Democracies." American Journal of Political Science 47(1), 91-109.

Aguilar, Edwin E. and Alexander Pacek C. 200o. "Macroeconomic Conditions, Voter Turnout, and the Working Class Economically Disadvantaged Party Vote in Developing Countries." Comparative Political Studies 33(8), 995-1017.

Berry, William D., Matt Golder, and Daniel Milton. 2012. "Improving Tests of Theories Positing Interaction.” The Journal of Politics 74(3), 653-671.

Brambor, Thomas, William R. Clark, and Matt Golder. 2006. "Understanding Interaction Models: Improving Empirical Analyses." Political Analysis 14(1), 63-82.

Braumoeller, Bear F. 2004. "Hypothesis Testing and Multiplicative Interaction Terms." International Organization 58(4), 807-820.

Budge, Ian and Dennis Farlie. 1983. Explaining and Predicting Elections: Issue Effects and Party Strategies in Twenty-three Democracies. London: George Allen and Unwin.

Budge, Ian. 1999. "Estimating Party Policy Preferences: From Ad Hoc Measurements to Theoretically Validated Standards." Paper presented at the Joint Sessions of the ECPR, Mannheim (March 26-31).

Chang, C. Eric and Miriam A. Golden. 2004. "Does Corruption Pay? The Survival of Politicians Charged with Malfeasance in the Postwar Italian Chamber." Paper presented at the Annual Meeting of the American Political Science Association, Hilton Chicago and the Palmer House Hilton, Chicago, IL (September 2-5).

Debus, Marc, Mary Stegmaier, and Jale Tosun. 2014. "Economic Voting under Coalition Governments: Evidence from Germany." Political Science Research and Methods 2(1), 49-67.

Duch, Raymond and Randy Stevenson. 2006. "Assessing the Magnitude of the Economic Vote over Time and Across Nations." Electoral Studies 25(3), 528-547.

. 2008. The Economic Voting: How Political and Economic Institutions Condition Election Results. New York: Cambridge University Press.

Fackler, Tim and Tse-min Lin 1995. "Political Corruption and Presidential Elections, 1929-1992.” The Journal of Politics 57(4), 971-993.

Fiorina, Morris. 1981. Retrospective Voting in American National Elections. 
New Haven, CT: Yale University Press.

Fossati, Diego. 2014. "Economic Vulnerability and Economic Voting in 14 OECD Countries." European Journal of Political Research 53(1), 116135 .

Sartori, Giovanni. 1976. "Spatial Competition.” In Giovanni Sartori ed., Parties and Party Systems: A Framework for Analysis. New York: Cambridge University Press.

Healy, Andrew and Gabriel S. Lenz. 2014. "Substituting the End for the Whole: Why Voters Respond Primarily to the Election-year Economy." American Journal of Political Science 58(1), 31-47.

Healy, Andrew, Mikael Persson, and Erik Snowberg. 2016. "Digging into the Pocketbook: Evidence on Economic Voting from Income Registry Data Matched to a Voter Survey." CESifo Working Paper Series No. 6171. Available at SSRN: https:ssrn.com

Hellwig, Timothy and David Samuels. 2007. "Electoral Accountability and the Variety of Democratic Regimes." British Journal of Political Science 38(1), 65-90.

Hellwig, Timothy. 2010. "Elections and the Economy." In Lawrence LeDuc, Richard G. Niemi, and Pippa Norris eds., Comparing Democracies 3. New York: SAGE Publications Inc.

. 2012. "Constructing Accountability: Party Position Taking and Economic Voting." Comparative Political Studies 45(1), 91-118.

Herzfeld, Thomas and Christoph Weiss. 2003. "Corruption and Legal (In) effectiveness: An Empirical Investigation.” European Journal of Political Economy 19(3), 621-632.

Hibbs, Douglass A. 1987. The American Political Economy. Cambridge, MA: Harvard University Press.

Inglehart, Ronald. 1971. "The Silent Revolution in Europe: Intergenerational Change in Post-Industrial Societies." The American Political Science Review 65(4), 991-1017.

. 1997. Modernization and Post-modernization: Cultural, Economics, and Political Change in 43 Societies. Princeton, NJ; Princeton University Press.

Kadane, Joseph B. 1972. "On Division of the Question." Public Choice 13, 4754 .

Key Jr., V. O. 1966. The Responsible Electorate. Cambridge, MA: Harvard University Press.

Kiewiet, D. Roderick. 1983. Macroeconomics and Micropolitics: The Electoral Effects of Issues. Chicago, IL: University of Chicago Press. 
Klašnja, Marko and Joshua A. Tucker. 2013. "The Economy, Corruption, and the Vote: Evidence from Experiments in Sweden and Moldova." Electoral Studies 32(3), 536-543.

Krause, Stefan and Fabio Méndez, F. 2009. "Corruption and Elections: An Empirical Study for a Cross-Section of Countries." Economics and Politics 21(2), 179-200.

Kramer, Gerald. 1972. "Sophisticated Voting over Multidimensional Choice Spaces." Journal of Mathematical Sociology 2(2), 165-180.

Krosnick, Jon A. 1988. "The Role of Attitude Importance in Social Evaluation: A Study of Policy Preferences, Presidential Candidate Evaluations, and Voting Behavior.” Journal of Personality and Social Psychology 55(2), 196-210.

Levi, Margaret. 1997. "A Model, a Method, and a Map: Rational Choice in Comparative and Historical Analysis." In Mark L. Lichbach and Alan S. Zuckerman eds., Comparative Politics: Rationality, Culture, and Structure. Cambridge: Cambridge University Press.

Lavine, Howard, John L. Sullivan, Eugene Borgida, and Cynthia J. Thomsen. 1996. "The Relationship of National and Personal Issue Salience to Attitude Accessibility on Foreign and Domestic Policy Issues." Political Psychology 17(2), 293-316.

Lewis-Beck, Michael S. and Glenn Mitchell. 1990. "Transnational Models of Economic Voting: Tests from a Western European Pool." Revista del Instituto de Estudios Economicos 4, 65-81.

Lewis-Beck, Michael S. and Mary Stegmaier. 2000. "Economic Determinants of Electoral Outcomes." Annual Review of Political Science 2000(3), 183-219.

Lewis-Beck, Michael S. 1997. "Who's the Chef? Economic Voting Under a Dual Executive." European Journal of Political Research 31(3), 315-325. 2001. "National Economic Voting in U.S. Presidential Elections." The Journal of Politics 63(1), 159-181.

Maslow, Abraham. 1954. Motivation and Personality. New York: Harper.

Mueller, John E. 1970. "Presidential Popularity from Truman to Johnson." American Political Science Review 64(1), 18-34.

Nadeau, Richard, Richard G. Niemi, and Antonie Yoshinaka. 2002. "A CrossNational Analysis of Economic Voting: Taking Account of the Political Context across Time and Nations." Electoral Studies 21(3), 403-423.

Paldam, Martin. 1991. "How Robust is the Vote Function? A Study of Seventeen Nations over Four Decades.” In Helmut Norpoth, Michael S. Lewis-Beck and Jean D. Lafay eds., The Calculus of Support. Ann 
Arbor, MI: University of Michigan Press.

Pereira, Carlos, Marcus André Melo, and Carlos M. Figueiredo. 2009. "The Corruption-Enhancing Role of Re-election Incentives? Counterintuitive Evidence from Brazil's Audit Reports." Political Research Quarterly 62(4), 639-652.

Persson, Torsten, Guido Tabellini, and Francesco Trebbi. 2003. "Electoral Rules and Corruption." Journal of the European Economic Association 1(4), 958-989.

Petrocik, John R. 1996. "Issue Ownership in Presidential Elections, with a 1980 Case Study." American Journal of Political Science 40(3), 825850.

Powell, G. Bingham and Guy D. Whitten. 1993. "A Cross-National Analysis of Economic Voting: Taking Account of the Political Context." American Journal of Political Science 37(2), 391-414.

Rabinowitz, George, James W. Prothro, and William Jacoby. 1982. "Salience as a Factor in the Impact of Issues on Candidate Evaluation." The Journal of Politics 44(1), 41-63.

Radcliff, Benjamin. 1992. "The Welfare State, Turnout, and the Economy." American Political Science Review 86(2), 444-456.

Rosas, Guillermo and Luigi Manzetti. 2015. "Reassessing the Trade-off Hypothesis: How Misery Drives the Corruption Effect on Presidential Approval." Electoral Studies 39(September), 26-38.

Shapiro, Michael J. 1969. "Rational Political Man: A Synthesis of Economic and Social Psychological Perspectives." American Political Science Review 63(4), 1106-1119.

Singer, Matthew M. 2011a. "Economic Voting and Welfare Programmes: Evidence from the American States." European Journal of Political Research 50(4), 479-503.

2011b. "Who Says It's the Economy?" Cross-National and CrossIndividual Variation in the Salience of Economic Performance." Comparative Political Studies 44(3), 284-312.

Slomczynski, Kazimierz and Goldie Shabad. 2011. "Perceptions of Political Party Corruption and Voting Behavior in Poland." Party Politics 18(6), 897-917.

Stevenson, Randolph T. and Lynn Vavreck. 2000. "Does Campaign Length Matter? Testing for Cross-National Effects." British Journal of Political Science 30(2), 217-235.

Stimson, James A. 1985. "Who Says Regression in Time and Space: A Statistical Essay." American Journal of Political Science 29(4), 914-947. 
Stokes, Donald E. 1963. "Spatial Models of Party Competition." American Political Science Review 57(2), 368-377.

Tucker, Joshua A. 2006. Regional Economic Voting: Russia, Poland, Hungary, Slovakia, and the Czech Republic, 1990-1999. New York: Cambridge University Press.

Tufte, Edward R. 1978. Political Control of the Economy. Princeton, NJ; Princeton University Press.

Van der Brug, Wouter, Cees van der Eijk, and Mark Franklin. 2007. The Economy and the Vote. New York: Cambridge University Press.

Van der Brug, Wouter. 2004. "Issue Ownership and Party Choice." Electoral Studies 23(2), 209-233.

Welch, Susan and John R. Hibbing. 1997. "The Effects of Charges of Corruption on Voting Behavior in Congressional Elections, 1982-1990." The Journal of Politics 59(1), 226-239.

Whitten, Guy D. and Harvey D. Palmer. 1999. "Cross-National Analyses of Economic Voting." Electoral Studies 18(1), 49-67.

Wlezien, Christopher and Robert S. Erikson. 1996. "Temporal Horizons and Presidential Election Forecasts.” American Politics Research 24(4), 492-505.

Wlezien, Christopher. 2015. "The Myopic Voter? The Economy and US Presidential Elections." Electoral Studies 39(3), 195-204.

Zechmeister, Elizabeth J. and Daniel Zizumbo-Colunga. 2013. "The Varying Political Toll of Concerns about Corruption in Good versus Bad Economic Times." Comparative Political Studies 46(10), 1155-1189.

[Received February 10, 2017; Revised March 14, 2017; Accepted April 7, 2017] 


\section{APPENDIX A. List of countries analyzed in this paper:}

Argentina, Australia, Austria, Bangladesh, Belgium, Bolivia, Brazil, Bulgaria, Canada, Colombia, Costa Rica, Denmark, El Salvador, Finland, France (Leg), France (Pre), Germany, Greece, Guatemala, Honduras, Hungary, India, Italy, Japan, Kenya, Malawi, Mexico, Netherlands, Nigeria, Norway, Portugal, Russia, South Korea, Spain, Sweden, Switzerland, Taiwan, Tanzania, Turkey, UK, USA, Uruguay

\section{APPENDIX B.}

The economic variables used in this paper were collected from The World Bank Data and TheGlobalEconomy.com. The corruption variables were collected from Transparency International. Following Krause and Méndez (2009), data on the ideology of incumbent parties and electoral results were obtained from three sources: the Dataset of Political Institutions (Beck et al. 2001), the Political Dataset of the Americas (managed by the Center for Latin American Studies at Georgetown University in collaboration with the Organization of American States), and the database for European political parties and elections. Finally, the ages of democracies were measured based on the Polity IV dataset.

- The World Bank Data (http://www.worldbank.org)

- TheGlobalEconomy.com (http://www.theglobaleconomy.com)

- Transparency International (http://www.transparency.org/research/cpi/ overview) 